\begin{abstract}
HETEROCYCLES, Vol. 94, No. 10, 2017, pp. 1870 - 1883. @ 2017 The Japan Institute of Heterocyclic Chemistry Received, 20th July, 2017, Accepted, 30th August, 2017, Published online, 4th September, 2017.
\end{abstract} DOI: $10.3987 / C O M-17-13781$

\title{
SYNTHESIS OF AZULENE-SUBSTITUTED TETRAARYLPYRROLES BY REACTION OF 1-AZULENYL KETONES WITH BENZOIN AND AMMONIUM ACETATE
}

Taku Shoji, ${ }^{a *}$ Sho Takagaki, ${ }^{a}$ Miwa Tanaka, ${ }^{a}$ Takanori Araki, ${ }^{a}$ Shuhei Sugiyama, ${ }^{\text {a }}$ Ryuta Sekiguchi, ${ }^{\mathrm{a}}$ Akira Ohta, ${ }^{\mathrm{a}}$ Shunji Ito, ${ }^{\mathrm{b}}$ and Tetsuo Okujima ${ }^{\mathrm{c}}$

a Department of Chemistry, Faculty of Science, Shinshu University, Matsumoto, 390-8621, Japan. E-mail: tshoji@shinshu-u.ac.jp

b Graduate School of Science and Technology, Hirosaki University, Hirosaki 036-8561, Japan

c Department of Chemistry and Biology, Graduate School of Science and Engineering, Ehime University, Matsuyama 790-8577, Japan

\begin{abstract}
Tetraarylpyrroles with a 1-azulenyl substituent were prepared by the reaction of 1-azulenyl ketones, which have various aryl-substituents at their $\alpha$-position, with benzoin in the presence of ammonium acetate as a nitrogen source of the pyrrole ring. Optical property of the tetraarylpyrroles obtained by the reaction was clarified by UV/Vis spectroscopy and/or time-dependent density functional theory (TD-DFT) calculations.
\end{abstract}

\section{INTRODUCTION}

A variety of synthetic methods for pyrrole derivatives have been developed so far, ${ }^{1}$ because the compounds having a pyrrole skeleton are found in numerous natural products and pharmaceuticals. ${ }^{2}$ In particular, the synthetic procedures for tetraarylpyrroles and their derivatives have been actively investigated in recent years, since the pyrrole derivatives with multiple aryl substituents have attracted the interest in the field of functional organic materials, such as luminescent materials, e.g., organic EL and LED, with high luminous efficiency and long emission lifetime. ${ }^{3}$

As a classical method, the dehydrative condensation reaction of 1,4-diketones with a primary amine, known as Paal-Knorr synthesis, has been employed for the synthesis of the pyrrole derivatives. ${ }^{4}$ However, there are some difficulties in the preparation of aryl-substituted 1,4-diketones, which become a good precursor for the arylpyrrole derivatives. As an alternative procedure, there is a dimerization method of aryl ketones in the presence of hydrazine via condensation reaction for the pyrrole synthesis, but this 
method requires a highly toxic and explosive reagent, i.e., hydrazine. ${ }^{5}$ As a modern methodology, stepwise introduction of aryl groups into the pyrrole ring by cross-coupling reaction has been reported, but the preparation of the pyrrole derivatives with different substituents at their 2- and 5-positions is rather difficult by the synthetic method. ${ }^{6}$ Despite the development of the synthetic methods in recent years, ${ }^{7}$ practical synthesis of tetraarylpyrroles is still limited owing to the less availability of their starting materials.

Azulene has attracted the interest of many research groups due to its unusual properties associated with its remarkable polarizability as well as its beautiful blue color. ${ }^{8}$ Although the various efficient and facile synthetic methods for azulene derivatives have also been developed in recent years, ${ }^{9}$ there are few works in the literature for the synthesis and properties of azulene-substituted pyrrole derivatives. In 2002, Murafuji et al. reported the preparation of 2,5-di(6-azulenyl)pyrrole derivative by the Suzuki-Miyaura cross-coupling reaction of 6-azulenylboronic acid ester with a 2,5-dibromopyrrole derivative. ${ }^{10}$ Eichen and co-workers demonstrated the Stille cross-coupling reaction of 2-(tributylstannyl)pyrrole with 1,3-dibromoazulene to afford 1,3-di(2-pyrrolyl)azulene in moderate yield. ${ }^{11}$ More recently, Gryko et al . reported the preparation of 2,5-di(5- and 6-azulenyl)pyrrolo[3,2-b]pyrroles by the Zieglar-Hafner azulene synthesis using di(3- and 4-pyridyl)pyrrolo[3,2-b]pyrroles as starting materials. ${ }^{12}$ We have demonstrated efficient synthetic procedures for several aromatic heterocyclic compounds having an azulene ring, as well as their spectroscopic and electrochemical properties, ${ }^{13}$ in which we have also reported the preparation of 1-(2-indolyl)azulene derivatives by $\mathrm{Tf}_{2} \mathrm{O}$-mediated Vilsmeier-Haak type arylation reaction. ${ }^{14}$ However, the synthesis of azulene-substituted pyrrole derivatives by the cyclization method to form the pyrrole ring has never been investigated so far. Furthermore, there is no literature for the preparation of tetraarylpyrrole derivatives substituted by an azulene ring.

Recently, Lei et al. reported that tetraarylpyrroles can be synthesized in moderate to high yields by the cyclization reaction of aryl ketones with benzoins in the presence of ammonium acetate as a nitrogen source of the pyrrole ring. ${ }^{15}$ We have investigated the applicability of this procedure to azulene derivatives for the development of novel synthetic route to obtain the synthetically difficult azulene-substituted tetraarylpyrroles.

In this paper, we describe the synthesis of azulene-substituted tetraarylpyrroles by the cyclization reaction of the 1-azulenyl ketones having a various aryl group at their $\alpha$-position with benzoin in the presence of ammonium acetate as a nitrogen source of the pyrrole ring, as well as their optical properties investigated by UV/Vis spectroscopy and TD-DFT calculations.

\section{RESULTS AND DISCUSSION}


As an initial attempt, the reaction conditions were optimized by using 1-azulenyl ketone 1a with a phenyl group at the $\alpha$-position (Table 1). When the reaction was carried out at $110{ }^{\circ} \mathrm{C}$ for 15 hours by using 1.5 molar equivalents of benzoin and 15 molar equivalents of ammonium acetate, the desired 2-(1-azulenyl)pyrrole derivative 2a with three phenyl substituents was obtained in 55\% yield (Entry 1), along with the formation of considerable amount of 2,3,4,5-tetraphenylpyrazine as a by-product. ${ }^{16}$ The yield of 2a (44\%) was not improved by the extension of the reaction time to 30 hours, due to the decomposition of the product (Entry 2). The use of 3 molar equivalents of benzoin and 30 molar equivalents of ammonium acetate led to some increase in the yield of the product (65\%, Entry 3 ). However, by using further excess reagents, the yield of 2a slightly decreased to 57\% (Entry 4). The best yield of $2 \mathrm{a}(66 \%)$ was obtained by the reaction at $100{ }^{\circ} \mathrm{C}$ by using 3 molar equivalents of benzoin and 30 molar equivalents of ammonium acetate (Entry 5). Therefore, this reaction condition was selected for further investigations for the synthesis of the tetraarylpyrroles with a 1-azulenyl substituent.

Table 1. Optimization of the reaction conditions
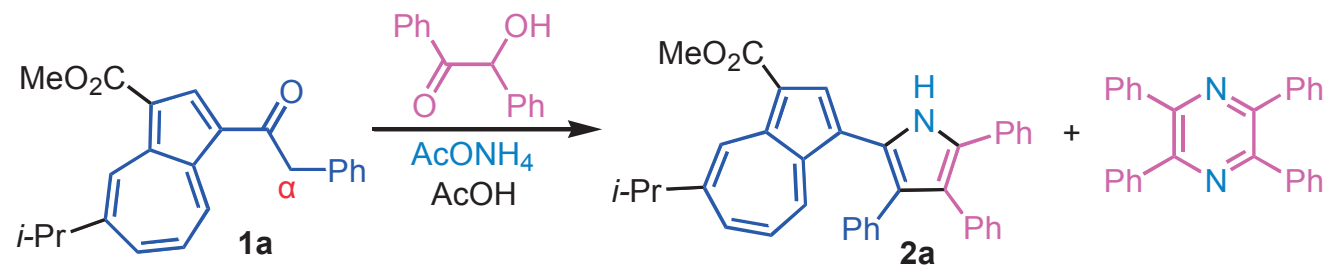

\begin{tabular}{llllll}
\hline Entry & Benzoin [eq.] & $\mathrm{AcONH}_{4}$ [eq.] & Reaction time $[\mathrm{h}]$ & Temperature $\left[{ }^{\circ} \mathrm{C}\right]$ & Yield $[\%]$ \\
\hline 1 & 1.5 & 15 & 15 & 110 & 55 \\
2 & 1.5 & 15 & 30 & 110 & 44 \\
3 & 3.0 & 30 & 15 & 110 & 65 \\
4 & 4.5 & 45 & 15 & 110 & 57 \\
5 & 3.0 & 30 & 15 & 100 & 66 \\
\hline
\end{tabular}

In order to investigate the scope of the procedure, we examined the reaction of several 1-azulenyl ketones with various aryl substituents at their $\alpha$-position with benzoin in the presence of ammonium acetate under the optimized reaction conditions. The 1-azulenyl ketones used in the reaction were prepared by the procedure reported by us, recently. ${ }^{17}$ The yield and structure of the products are summarized in Figure 1. Lei et al. reported that the tetraarylpyrroles are given in good to excellent yields regardless of the nature of their substituent on the aryl groups both in aryl ketones with benzoins, i.e., electron-donating or electron-withdrawing natures, ${ }^{15}$ but we found that the yield of the pyrrole derivatives is significantly affected by the aryl substituents at their $\alpha$-position on the 1-azulenyl ketones. 
The ketone $\mathbf{1 b}$ with a $N, N$-dimethylaminophenyl group reacted under the conditions to give the pyrrole $\mathbf{2 b}$ in $60 \%$ yield, along with the undesired 2,3,5,6-tetraphenylpyrazine as a by-product. Similarly, the condensation reaction of 1-azulenyl ketone $1 \mathrm{c}$ with a 1 -azulenyl substituent at the $\alpha$-position afforded the corresponding cyclization product $\mathbf{2 c}$ in $42 \%$ yield. Some decrease in the yield of the product $\mathbf{2 c}$ might be attributed to the low solubility of 1c under the conditions. However, the yield of pyrrole 2d was significantly decreased to $2.7 \%$ by the reaction of 1 -azulenyl ketone $1 \mathbf{d}$ under the similar reaction conditions. This is attributed to the low reactivity of the ketone 1d to form the pyrrole ring, since the most of the starting material was recovered and a large amount of 2,3,5,6-tetraphenylpyrazine was generated in this cases. As similar to the results described above, ketone 1e was reacted to afford the corresponding pyrrole derivative $2 \mathrm{e}$ in $66 \%$ yield. Ketone derivatives $\mathbf{1 f}, \mathbf{1 g}$ and $\mathbf{1 h}$ with a 1 -phenylazulene moiety were also reacted under the same conditions to give the corresponding pyrroles $\mathbf{2 f}(28 \%), \mathbf{2 g}(50 \%)$ and $\mathbf{2 h}$ $(11 \%)$.

It should be concluded that the reaction of 1-azulenyl ketones with an electron-donating aryl substituent, such as $N, N$-dimethylaminophenyl and $2 H$-2-oxocyclohepta[b]furan-3-yl groups, at their $\alpha$-position afforded the products in relatively good yields. On the other hand, strong electron-withdrawing group at their $\alpha$-position, e.g., $p$-nitrophenyl and 6-azulenyl groups, decreased the yield of the reaction products, significantly. This should be marked difference in the observation reported by Lei et al.

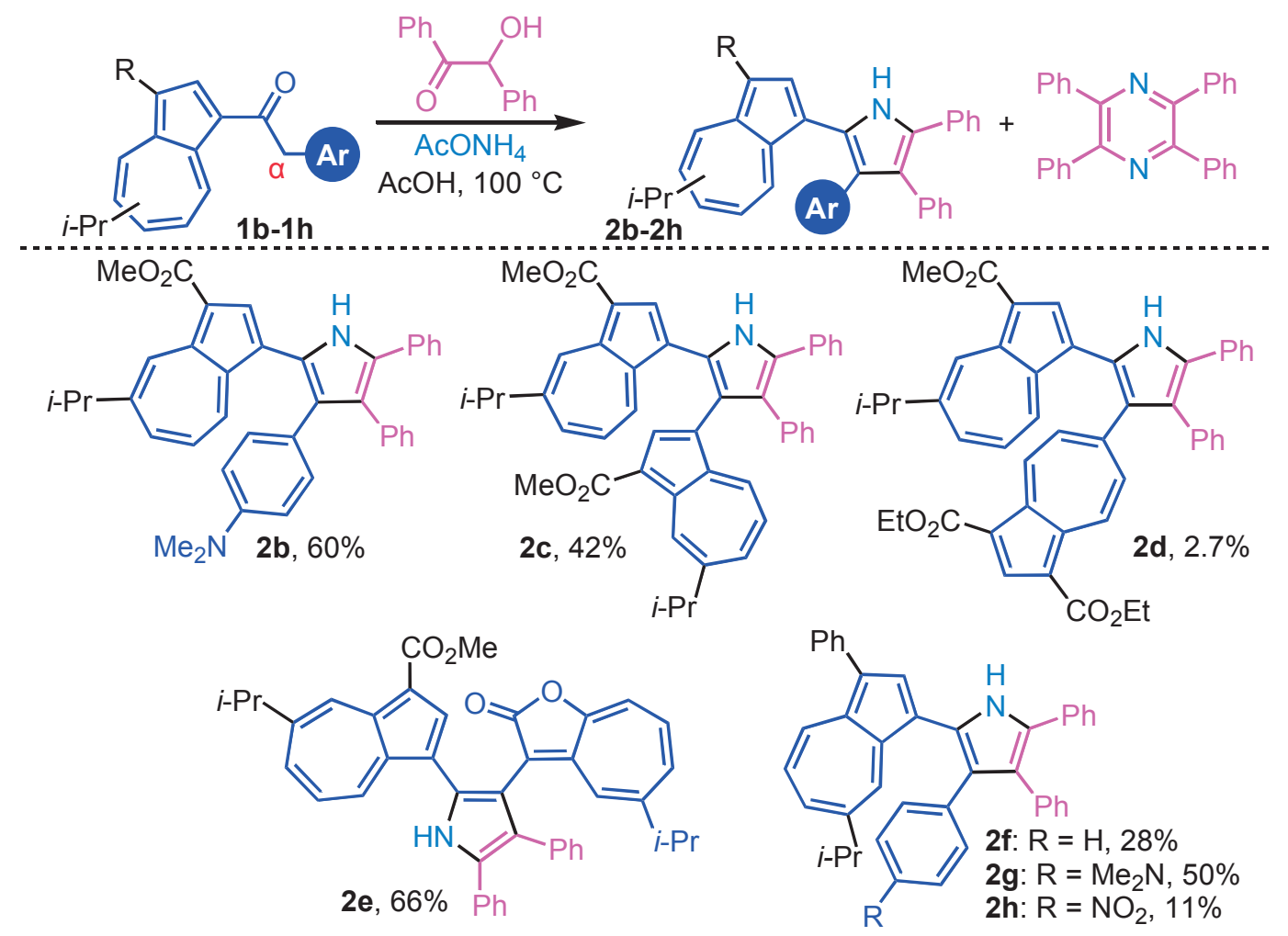

Figure 1. Structure and yield of the tetraarylpyrroles with a 1-azulenyl substituent $\mathbf{2} \mathbf{b}-\mathbf{2 h}$ 
Presumed reaction mechanism for the formation of the pyrrole ring was illustrated in Scheme 1. Initially, the reaction of benzoin with ammonia, which is provided by ammonium acetate, produces an imine intermediate $\mathbf{A}$ with the elimination of water. Then the imine is transformed to $\alpha$-amino ketone $\mathbf{B}$ by the tautomerization involving proton transfer. The condensation reaction of amine moiety of $\mathbf{B}$ with 1-azulenyl ketones proceeds to afford the imine intermediate $\mathbf{C}$, which isomerizes to highly reactive enamine D. Followed intramolecular nucleophilic reaction gives the pyrroline intermediate E. Finally, the pyrrole $\mathbf{G}$ is obtained via intramolecular dehydration of $\mathbf{E}$ and tautomerization of $\mathbf{F}$.

The difference of the yield of the products might depend on the reactivity of the enamine intermediate $\mathbf{D}$ owing to the differences in aryl substituent on 1-azulenyl ketones. For example, an enamine intermediate with a $p$-nitrophenyl group, which is a strong electron-withdrawing group, causes the delocalization of enamine lone-pair electron to the nitro group by the resonance (Scheme 2). Therefore, the nucleophilicity of the enamine moiety should be significantly decreased for the progress of the intramolecular cyclization reaction.
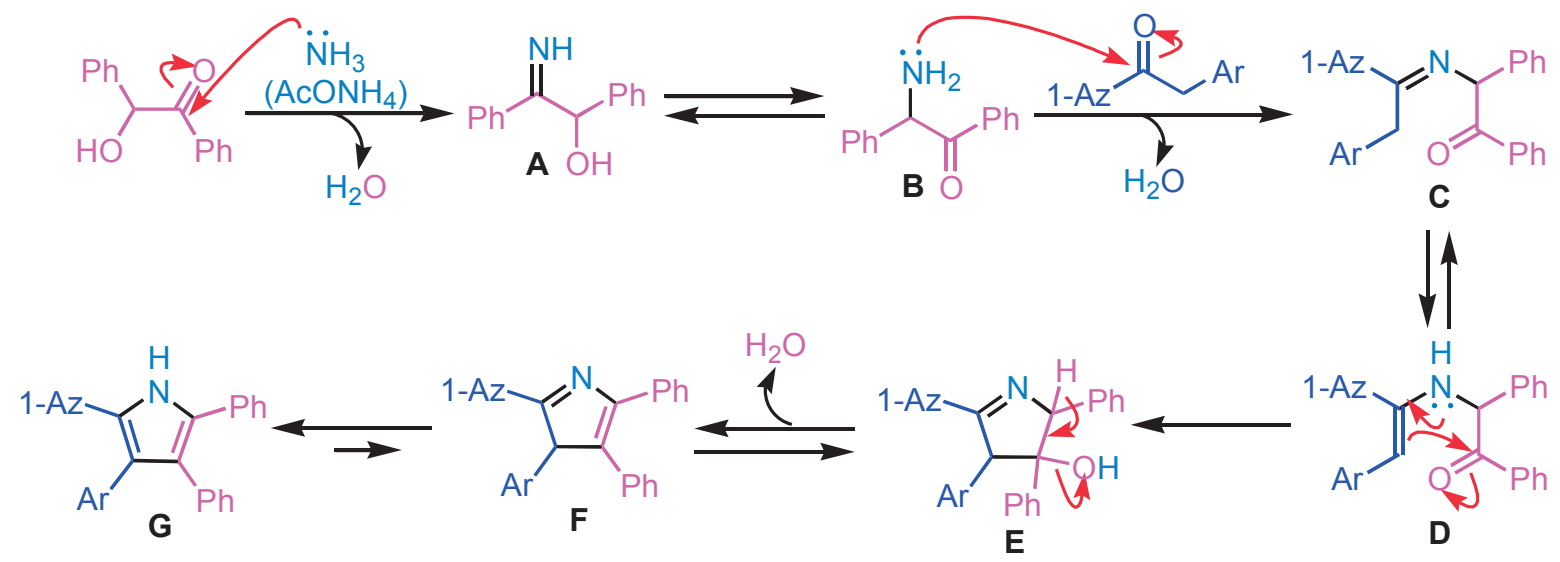

Scheme 1. Presumed reaction mechanism for the formation of tetraarylpyrroles

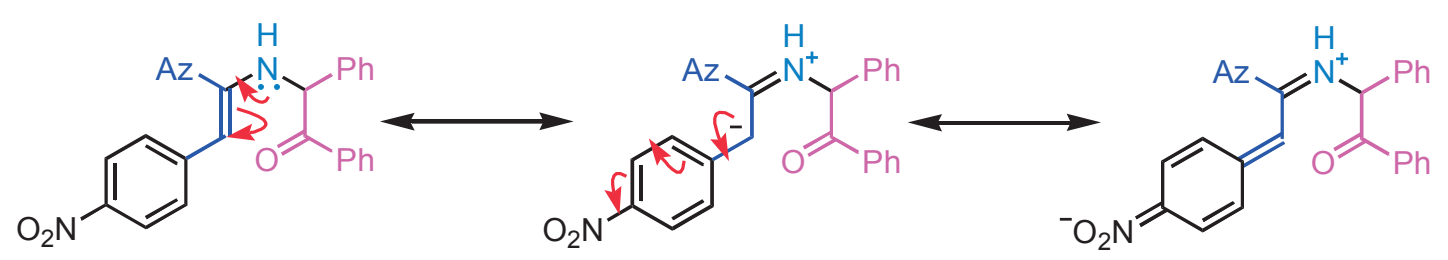

Scheme 2. Presumed resonance effect of enamine intermediate $\mathbf{D}$ with a $p$-nitrophenyl group

These new compounds were fully characterized on the basis of their spectral data, as summarized in the Experimental Section. HRMS of compounds $\mathbf{2 a}-\mathbf{2 h}$ ionized by FAB-MS showed the expected molecular ion peaks. These results show the correctness of the structure of the new compounds.

UV/Vis spectra of $\mathbf{2 f}, \mathbf{2} \mathbf{g}$ and $\mathbf{2 h}$ in $\mathrm{CH}_{2} \mathrm{Cl}_{2}$ are shown in Figure 2. The UV/Vis spectra of the tetraarylpyrrole derivatives $\mathbf{2} \mathbf{a}-\mathbf{2 h}$ with a 1-azulenyl substituent showed a weak absorption band in the 
visible region in $\mathrm{CH}_{2} \mathrm{Cl}_{2}$. The extinction coefficients of the absorption band of $\mathbf{2} \mathbf{c}$ and $\mathbf{2 d}$ in the visible region were increased, compared to the other derivatives, because of the overlap of the transition originated from the two azulene moieties.

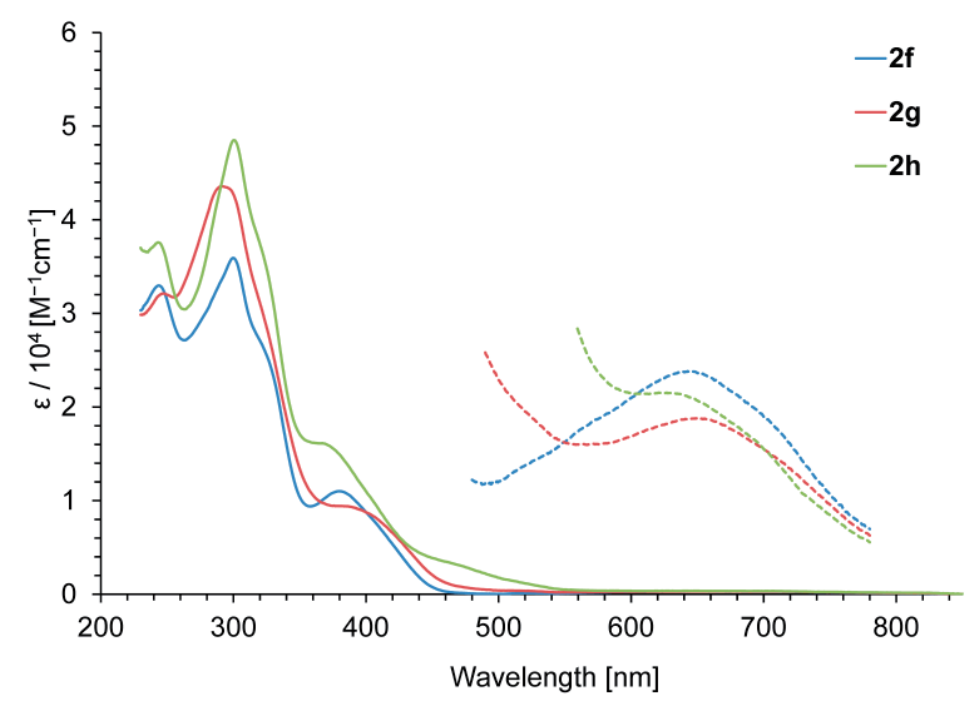

Figure 2. UV/Vis spectra of $\mathbf{2} \mathbf{f}$ (blue line), $\mathbf{2 g}$ (red line), and $\mathbf{2 h}$ (light-green line) in $\mathrm{CH}_{2} \mathrm{Cl}_{2}$
Slight bathochromic shift for the longest wavelength absorption band of $\mathbf{2} \mathbf{f}, \mathbf{2} \mathbf{g}$ and $\mathbf{2 h}$, compared with that of the 1-phenyl-5-isopropylazulene $\left(\lambda_{\max }=608\right.$ $\mathrm{nm})^{18}$ might be attributed to the extension of the $\pi$-electron system by the triarylpyrrole moiety. The longest wavelength absorption band of $\mathbf{2} \mathbf{f}, \mathbf{2} \mathbf{g}$ and $\mathbf{2 h}$ in the UV/Vis spectra was depended on the nature of the para-substituent on the aryl group on the pyrrole ring. Compound 2f exhibited the absorption band at $\lambda_{\max }=$ $639 \mathrm{~nm}$. The UV/Vis spectrum of the $\mathbf{2 g}$ with $N, N$-dimethylamino function exhibited the absorption band at $\lambda_{\max }=652 \mathrm{~nm}$. The longest wavelength band of $\mathbf{2 h}$ with a $p$-nitrophenyl group $\left(\lambda_{\max }=629 \mathrm{~nm}\right)$ displayed a hypsochromic shift, compared with those of $\mathbf{2} \mathbf{f}$ and $\mathbf{2 g}$.

To elucidate the nature of the absorption bands, time-dependent density functional theory (TD-DFT) calculations at the B3LYP/6-31G** level $^{19}$ were carried out on $\mathbf{2 f}, \mathbf{2 g}$ and $\mathbf{2 h}$. The frontier Kohn-Sham orbitals of these compounds are shown in Figure 3. The theoretical calculations revealed the difference in the longest wavelength absorption maxima and the HOMO-LUMO energy gap of the $\mathbf{2} \mathbf{f}, \mathbf{2} \mathbf{g}$ and $\mathbf{2 h}$, depended on the para-substituent on the aryl group at the 3-position of the pyrrole ring.

The longest wavelength absorption band at $\lambda_{\max }=639 \mathrm{~nm}$ of $\mathbf{2} \mathbf{f}$ should be considered as the transition from the HOMO, which was located on the both pyrrole and 1-azulenyl moieties, to the LUMO, which was located on the azulene ring (Table 2). Thus, the absorption band could be assumed as the overlap of the transition from pyrrole to 1-azulenyl group and azulene ring itself. As shown in Table 2, the absorption bands of $\mathbf{2 g}$ and $\mathbf{2 h}$ were also revealed as the transition from the HOMO located on the pyrrole moiety to LUMO spread in the azulene moiety, but the energy gaps between HOMO and LUMO were different from each other.

Calculated HOMO-LUMO gap of $\mathbf{2 g}(2.50 \mathrm{eV})$ was lower than those of $\mathbf{2 f}(2.62 \mathrm{eV})$ and $\mathbf{2 h}(2.67 \mathrm{eV})$, because the HOMO level was effectively raised by the strong electron-donating $N, N$-dimethylamino group. Thus, the $N, N$-dimethylaminophenyl moiety in $\mathbf{2 g}$ should contribute to decrease in the 
HOMO-LUMO gap, resulted into the bathochromic shift of the longest wavelength absorption band of $\mathbf{2 g}$, compared to those of $\mathbf{2} \mathbf{f}$ and $\mathbf{2 h}$. Whereas, the compound $\mathbf{2 h}$ having a $p$-nitrophenyl group showed slight hypsochromic shift, due to the opposite effect on the $N, N$-dimethylaminophenyl group, i.e., electron-withdrawing nature of the $p$-nitrophenyl group, to derive the higher HOMO-LUMO gap energy.

Table 2. Electronic transitions for $\mathbf{2 f}, \mathbf{2 g}$ and $\mathbf{2 h}$ derived from the computed values based on B3LYP/6-31G** method and experimental values

\begin{tabular}{|c|c|c|c|c|}
\hline \multirow[t]{2}{*}{ Sample } & Experimental & \multicolumn{3}{|c|}{ Computed Value } \\
\hline & $\lambda_{\max }(\log \varepsilon)$ & $\lambda_{\max }$ (strength) & Composition of band ${ }^{\mathrm{a}}$ (amplitude) & $\mathrm{H}-\mathrm{L}^{\mathrm{a}}$ gap $[\mathrm{eV}]$ \\
\hline $2 f$ & $639(2.68)$ & $645(0.0049)$ & $\mathrm{H} \rightarrow \mathrm{L}(0.9820)$ & 2.62 \\
\hline $2 \mathrm{~g}$ & $652(2.57)$ & $673(0.0049)$ & $\mathrm{H} \rightarrow \mathrm{L}(0.9720)$ & 2.50 \\
\hline $2 \mathrm{~h}$ & $629(2.63)$ & $632(0.0056)$ & $\mathrm{H} \rightarrow \mathrm{L}(0.9690)$ & 2.67 \\
\hline
\end{tabular}

${ }^{\mathrm{a}} \mathrm{H}=\mathrm{HOMO}, \mathrm{L}=\mathrm{LUMO}$
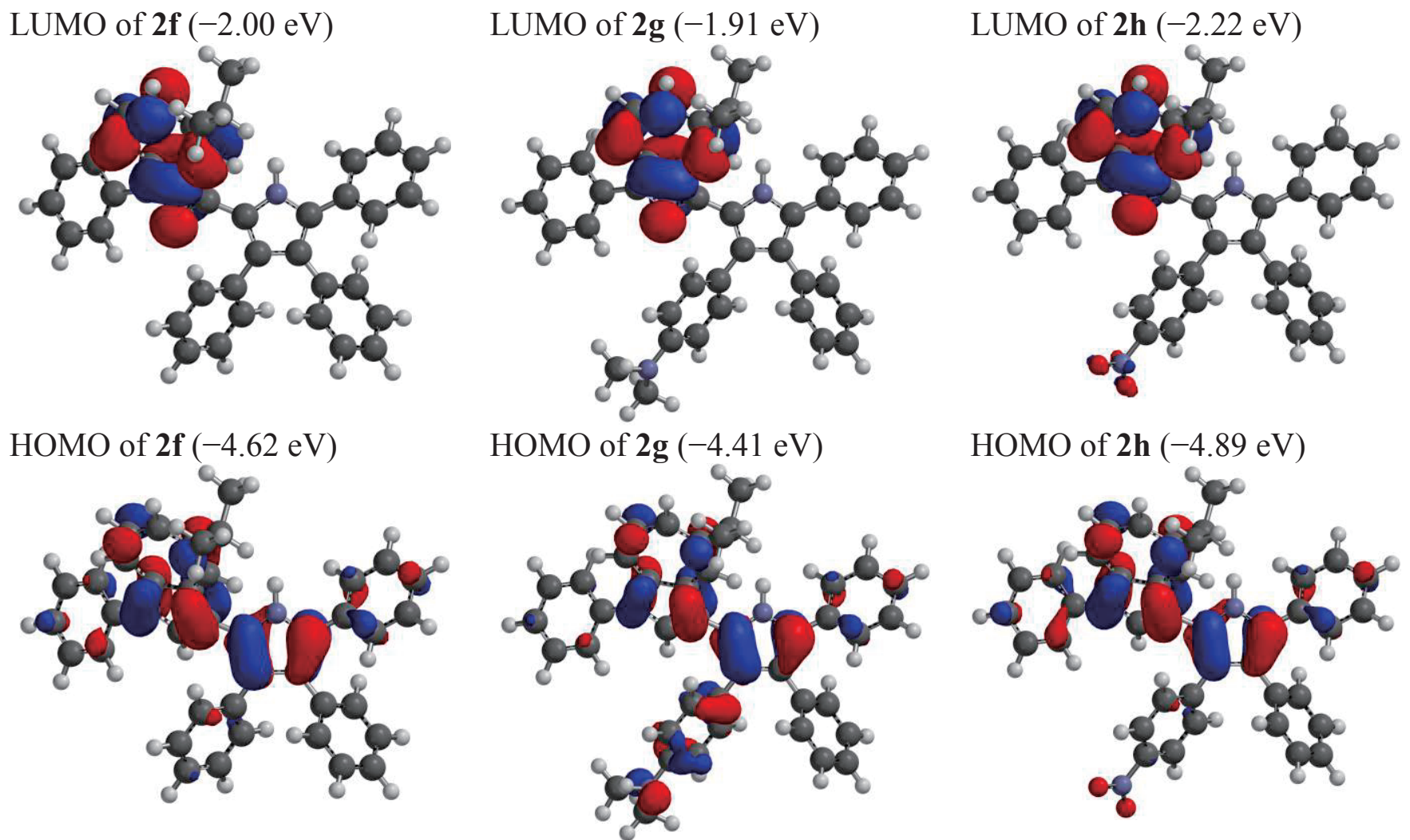

Figure 3. Frontier Kohn-Sham orbitals of $\mathbf{2 f}$ (left), $\mathbf{2 g}$ (center), and $\mathbf{2 h}$ (right) at the B3LYP/6-31G** level 


\section{CONCLUSION}

In conclusion, a series of tetraarylpyrroles $\mathbf{2} \mathbf{a}-\mathbf{2 h}$ with a 1-azulenyl substituent were prepared by the cyclization reaction of 1 -azulenyl ketones $\mathbf{1 a}-\mathbf{1 h}$ bearing various aryl groups on the $\alpha$-position with benzoin in the presence of ammonium acetate as a nitrogen source of the pyrrole ring. The method opens up a novel synthetic pathway for the azulene-substituted tetraarylpyrroles, despite the yield of the products is depended on the aryl substituent on the 1-azulenyl ketones. Origin of the absorption bands of $\mathbf{2 f}, \mathbf{2} \mathbf{g}$ and $\mathbf{2 h}$ found in their UV/Vis spectra were characterized by TD-DFT calculations. These results would warrant the development of the new synthetic methodology for azulene derivatives connected with aromatic heterocyclic compounds.

\section{EXPERIMENTAL}

Melting points were determined with a Yanagimoto MPS3 micro melting apparatus and are uncorrected. High-resolution mass spectra were obtained with a JEOL JMS-700 instrument. IR and UV/Vis spectra were measured with JASCO FT/IR-4100 and Shimadzu UV-2550 spectrophotometer. ${ }^{1} \mathrm{H}$ and ${ }^{13} \mathrm{C}$ NMR spectra were recorded in $\mathrm{CDCl}_{3}$ or DMSO- $d_{6}$ with a JEOL ECA500 spectrometer at $500 \mathrm{MHz}$ and 125 $\mathrm{MHz}$, respectively.

Compound 2a: Ammonium acetate $(698 \mathrm{mg}, 9.05 \mathrm{mmol})$ was added to a solution of 1a (105 $\mathrm{mg}, 0.303$ mmol) and benzoin $(195 \mathrm{mg}, 0.919 \mathrm{mmol})$ in acetic acid $(2 \mathrm{~mL})$. The resulting mixture was stirred at $100{ }^{\circ} \mathrm{C}$ for $15 \mathrm{~h}$ under an $\mathrm{Ar}$ atmosphere. The reaction mixture was poured into water and extracted with $\mathrm{CH}_{2} \mathrm{Cl}_{2}$. The organic layer was washed with brine, dried over $\mathrm{Na}_{2} \mathrm{SO}_{4}$, and concentrated under reduced pressure. The residue was purified by column chromatography on silica gel with $\mathrm{CH}_{2} \mathrm{Cl}_{2}$ to give $2 \mathbf{a}$ (104 mg, 66\%). Mp 249-250 ${ }^{\circ} \mathrm{C}$; IR (AT-IR): $v_{\max }=3055$ (w), 2958 (m), 2925 (w), 1601 (m), 1571 (m), 1504 (m), 1486 (m), 1447 (m), 1428 (m), 1397 (m), 1353 (m), 1308 (w), 1251 (w), 1230 (w), 1179 (w), 1156 (w), 1102 (w), 1071 (m), 1031 (m), 1013 (m), 958 (w), 913 (m), 876 (m), 844 (m), 794 (m), 763 (s), 738 (m), $673(\mathrm{~m}), 660(\mathrm{~m}) \mathrm{cm}^{-1}$; UV/Vis $\left(\mathrm{CH}_{2} \mathrm{Cl}_{2}\right): \lambda_{\max }(\log \varepsilon)=241$ (4.54), 289 (4.61), $322 \mathrm{sh}$ (4.38), 381 (3.88), $421 \mathrm{sh}$ (3.79), $584(2.75) \mathrm{nm} ;{ }^{1} \mathrm{H}$ NMR (500 MHz, $\left.\mathrm{CDCl}_{3}\right): \delta_{\mathrm{H}}=9.68(\mathrm{~s}, 1 \mathrm{H}, 4-\mathrm{H}), 8.53(\mathrm{~s}, 1 \mathrm{H}$, NH), 8.27 (s, 1H, 2-H), 8.12 (d, 1H, $J=10.0 \mathrm{~Hz}, 8-\mathrm{H}), 7.60$ (d, 1H, J=10.0 Hz, 6-H), 7.30-7.32 (m, 2H, Ph-H), 7.26 (t, 2H, J=7.0 Hz, Ph-H), 7.18-7.20 (m, 6H, Ph-H), 7.06 (t, 1H, J=10.0 Hz, 7-H), 6.98-6.93 (m, 5H, Ph-H), 3.93 (s, 3H, CO $2 \mathrm{Me}), 3.16(\mathrm{t}, 1 \mathrm{H}, J=6.9 \mathrm{~Hz}, i-\mathrm{Pr}), 1.39$ (d, $6 \mathrm{H}, J=6.9 \mathrm{~Hz}, i-\mathrm{Pr}) \mathrm{ppm} ;{ }^{13} \mathrm{C}$ $\operatorname{NMR}\left(125 \mathrm{MHz}, \mathrm{CDCl}_{3}\right): \delta_{\mathrm{C}}=165.91,149.25,141.53,140.71,140.48,138.69,137.98,136.36,136.05$, $135.83,133.13,131.32$, 130.39, 129.17, 128.67, 128.11, 127.82, 127.20, 126.58, 126.14, 125.48, 124.96, $124.39,122.74,120.33,115.04,51.07,39.15,24.64 \mathrm{ppm}$, one signal in the aromatic region is overlapped with the other signals; HRMS (FAB-MS): calcd for $\mathrm{C}_{37} \mathrm{H}_{31} \mathrm{NO}_{2}{ }^{+}[\mathrm{M}]^{+}$521.2355, found: 521.2326. 
Compound 2b: The procedure used for the preparation of $\mathbf{2 a}$ was adopted here. The reaction of $\mathbf{1 b}$ (292 $\mathrm{mg}, 0.347 \mathrm{mmol})$ with benzoin $(116 \mathrm{mg}, 0.547 \mathrm{mmol})$ and ammonium acetate $(451 \mathrm{mg}, 5.85 \mathrm{mmol})$ in acetic acid $(1.3 \mathrm{~mL})$ at $100{ }^{\circ} \mathrm{C}$ for $15 \mathrm{~h}$ afforded $\mathbf{2 b}(62 \mathrm{mg}, 60 \%)$. Mp 275-277 ${ }^{\circ} \mathrm{C}$; IR (AT-IR): $v_{\max }=$ 3329 (w), 2945 (w), 1665 (s), 1606 (m), 1572 (w), 1532 (m), 1497 (w), 1455 (s), 1415 (m), 1381 (m), 1360 (m), 1307 (w), 1248 (m), 1216 (s), 1167 (m), 1130 (m), 1069 (m), 1046 (m), 1016 (w), 940 (w), 903 (m), $876(\mathrm{w}), 849$ (w), 818 (m), 798 (w), 775 (s), 768 (s), 729 (w), 700 (s), 671 (w), $656(\mathrm{w}) \mathrm{cm}^{-1}$; $\mathrm{UV} / \mathrm{Vis}\left(\mathrm{CH}_{2} \mathrm{Cl}_{2}\right): \lambda_{\max }(\log \varepsilon)=243$ (4.56), 286 (4.76), $322 \mathrm{sh}(4.49), 418 \mathrm{sh}(3.83), 590(2.81) \mathrm{nm} ;{ }^{1} \mathrm{H}$ $\operatorname{NMR}\left(500 \mathrm{MHz}, \mathrm{CDCl}_{3}\right): \delta_{\mathrm{H}}=9.70(\mathrm{~s}, 1 \mathrm{H}, 4-\mathrm{H}), 8.38(\mathrm{~s}, 1 \mathrm{H}, \mathrm{NH}), 8.30(\mathrm{~s}, 1 \mathrm{H}, 2-\mathrm{H}), 8.21(\mathrm{~d}, 1 \mathrm{H}, J=$ $10.0 \mathrm{~Hz}, 8-\mathrm{H}), 7.62$ (d, 1H, J=10.0 Hz, 6-H), 7.27-7.17 (m, 10H, Ph-H), 7.12 (t, 1H, J=10.0 Hz, 7-H), $6.80\left(\mathrm{~d}, 2 \mathrm{H}, J=8.6 \mathrm{~Hz}, o-\mathrm{H}\right.$ of $\left.p-\mathrm{Me}_{2} \mathrm{NPh}\right), 6.39$ (d, $2 \mathrm{H}, J=8.6 \mathrm{~Hz}, m-\mathrm{H}$ of $\left.p-\mathrm{Me}_{2} \mathrm{NPh}\right), 3.92(\mathrm{~s}, 3 \mathrm{H}$, $\mathrm{CO}_{2} \mathrm{Me}$ ), 3.18 (sept, $1 \mathrm{H}, J=6.9 \mathrm{~Hz}, i$-Pr), 2.79 (s, $6 \mathrm{H}, \mathrm{NMe}_{2}$ ), 1.40 (d, $6 \mathrm{H}, J=6.9 \mathrm{~Hz}, i$-Pr) ppm; ${ }^{13} \mathrm{C}$ NMR (125 MHz, $\left.\mathrm{CDCl}_{3}\right): \delta_{\mathrm{C}}=166.01,149.10,148.42,141.49,140.73,140.55,138.70,137.78,136.58$, $136.20,133.15,131.30,130.86,128.86,128.61,128.05,127.16,126.69,126.40,125.89$, 124.30, 124.14, 123.85, 122.40, 120.76, 114.72, 112.44, 51.14, 40.68, 39.14, 24.70 ppm; HRMS (FAB-MS): calcd for $\mathrm{C}_{39} \mathrm{H}_{36} \mathrm{~N}_{2} \mathrm{O}_{2}{ }^{+}[\mathrm{M}]^{+}$564.2777, found: 564.2791.

Compound 2c: The procedure used for the preparation of $\mathbf{2 a}$ was adopted here. The reaction of $\mathbf{1 c}$ (37 $\mathrm{mg}, 0.075 \mathrm{mmol})$ with benzoin $(157 \mathrm{mg}, 0.269 \mathrm{mmol})$ and ammonium acetate $(178 \mathrm{mg}, 2.31 \mathrm{mmol}) \mathrm{in}$ acetic acid $(1.5 \mathrm{~mL})$ at $100{ }^{\circ} \mathrm{C}$ for $15 \mathrm{~h}$ afforded $2 \mathrm{c}(21 \mathrm{mg}, 42 \%)$. Mp $277{ }^{\circ} \mathrm{C}$; IR (AT-IR): $v_{\max }=3294$ (w), 2955 (w), 2925 (w), 1686 (m), 1658 (m), 1604 (w), 1533 (w), 1497 (w), 1470 (m), 1446 (s), 1415 (m), 1397 (w), 1362 (w), 1299 (w), 1260 (w), 1235 (m), 1214 (s), 1169 (m), 1129 (m), 1076 (m), 1015 (m), 949 (w), 901 (m), $879(w), 855$ (w), 805 (m), 777 (s), 746 (w), $733(\mathrm{w}), 701$ (s), 681 (w), 657 (w) $\mathrm{cm}^{-1}$; UV/Vis $\left(\mathrm{CH}_{2} \mathrm{Cl}_{2}\right): \lambda_{\max }(\log \varepsilon)=243$ (4.70), 287 (4.82), 309 (4.72), 388 (4.14), $582(3.04) \mathrm{nm} ;{ }^{1} \mathrm{H}$ NMR (500 MHz, $\left.\mathrm{CDCl}_{3}\right): \delta_{\mathrm{H}}=9.55(\mathrm{~s}, 1 \mathrm{H}, 4-\mathrm{H}$ or 4'-H), 9.51 (s, 1H, 4-H or 4'-H), $8.75(\mathrm{~s}, 1 \mathrm{H}, \mathrm{NH})$, 8.15 (s, 1H, 2-H or 2'-H), 8.08 (d, 1H, J = 9.7 Hz, 8-H or 8'-H), 7.97-7.99 (m, 2H, 2-H or 2'-H, and 8-H or 8'-H), 7.49 (d, 1H, $J=10.3 \mathrm{~Hz}, 6-\mathrm{H}$ or 6'-H), 7.42 (d, 1H, $J=10.3 \mathrm{~Hz}, 6-\mathrm{H}$ or 6'-H), 7.38 (d, 2H, $J=$ $7.4 \mathrm{~Hz}, \mathrm{Ph}-\mathrm{H}$ ), 7.30 (t, 2H, J=7.7 Hz, Ph-H), 7.23 (t, 1H, J= $7.3 \mathrm{~Hz}, \mathrm{Ph}-\mathrm{H}$ ), 7.06 (br.s, 5H, Ph-H), 6.92-6.85 (m, 2H, 7,7'-H), 3.88 (s, 3H, CO $2 \mathrm{Me}$ ), 3.82 (s, 3H, $\left.\mathrm{CO}_{2} \mathrm{Me}\right), 3.08$ (sept, 2H, $J=6.8 \mathrm{~Hz}, i-\mathrm{Pr}$ ), $1.32\left(\mathrm{~m}, 12 \mathrm{H}, i\right.$-Pr) ppm; $\left.{ }^{13} \mathrm{C} \mathrm{NMR} \mathrm{(125} \mathrm{MHz,} \mathrm{CDCl}_{3}\right): \delta_{\mathrm{C}}=166.21,165.92,149.10,148.00,142.43$, $141.37,141.19,140.17,139.91,138.64,137.73,137.63,136.85,135.91,135.75,135.66,133.06,130.53$, $129.08,128.73,128.03,127.17,126.58,126.44,125.90,125.72,124.15,123.31,120.45,118.28,114.67$, $114.29,51.11,50.90,39.04,39.01,24.64,24.58 \mathrm{ppm}$, two signals in the aromatic region are overlapped with the other signals; HRMS (FAB-MS): calcd for $\mathrm{C}_{46} \mathrm{H}_{41} \mathrm{NO}_{4}{ }^{+}[\mathrm{M}]^{+} 671.3036$, found: 671.3040. 
Compound 2d: The procedure used for the preparation of $\mathbf{2 a}$ was adopted here. The reaction of $\mathbf{1 d}$ (92 $\mathrm{mg}, 0.17 \mathrm{mmol})$ with benzoin $(108 \mathrm{mg}, 0.509 \mathrm{mmol})$ and ammonium acetate $(366 \mathrm{mg}, 4.75 \mathrm{mmol})$ in acetic acid $(1.5 \mathrm{~mL})$ at $100{ }^{\circ} \mathrm{C}$ for $15 \mathrm{~h}$ afforded $2 \mathrm{~d}(3 \mathrm{mg}, 2.7 \%)$. Mp $283{ }^{\circ} \mathrm{C}$; IR (AT-IR): $v_{\max }=3288$ (w), 2960 (w), 2859 (w), 1688 (s), 1663 (m), 1577 (m), 1507 (w), 1432 (s), 1411 (s), 1389 (m), 1359 (w), 1308 (w), 1245 (m), 1200 (s), 1170 (m), 1131 (w), 1119 (w), 1092 (m), 1080 (m), 1044 (s), 999 (w), 982 (w), $936(\mathrm{w}), 908(\mathrm{w}), 893(\mathrm{w}), 866(\mathrm{~m}), 842(\mathrm{w}), 821(\mathrm{w}), 812(\mathrm{w}), 778(\mathrm{~m}), 736(\mathrm{w}), 697(\mathrm{~m}), 676(\mathrm{w})$, $660(\mathrm{w}), 651(\mathrm{w}) \mathrm{cm}^{-1}$; UV/Vis $\left(\mathrm{CH}_{2} \mathrm{Cl}_{2}\right): \lambda_{\max }(\log \varepsilon)=234$ (4.82), 281 (4.78), $303 \mathrm{sh}$ (4.75), $320 \mathrm{sh}$ (4.72), $376 \mathrm{sh}$ (4.43), $473 \mathrm{sh}(3.72) \mathrm{nm} ;{ }^{1} \mathrm{H}$ NMR (500 MHz, $\left.\mathrm{CDCl}_{3}\right)$ : $\delta_{\mathrm{H}}=9.74(\mathrm{~s}, 1 \mathrm{H}), 9.25$ (d, 2H, $J=$ $10.9 \mathrm{~Hz}), 8.68(\mathrm{~s}, 1 \mathrm{H}), 8.62(\mathrm{~s}, 1 \mathrm{H}), 8.24(\mathrm{~s}, 1 \mathrm{H}), 8.16(\mathrm{~d}, 1 \mathrm{H}, J=9.7 \mathrm{~Hz}), 7.63$ (d, 1H, J = 10.6 Hz), 7.50 $(\mathrm{d}, 2 \mathrm{H}, J=10.9 \mathrm{~Hz}), 7.30(\mathrm{~d}, 4 \mathrm{H}, J=4.3 \mathrm{~Hz}), 7.21-7.22(\mathrm{~m}, 3 \mathrm{H}), 7.12-7.14(\mathrm{~m}, 2 \mathrm{H}), 4.33(\mathrm{q}, 4 \mathrm{H}, J=7.2$ $\mathrm{Hz}, \mathrm{CO}_{2} \mathrm{Et}$ ), 3.90 (s, 3H, CO $2 \mathrm{Me}$ ), 3.16 (sept, $\left.1 \mathrm{H}, J=6.9 \mathrm{~Hz}, i-\mathrm{Pr}\right), 1.38$ (m, 12H, $\left.i-\mathrm{Pr}, \mathrm{CO}_{2} \mathrm{Et}\right) \mathrm{ppm} ;{ }^{13} \mathrm{C}$ NMR (125 MHz, $\left.\mathrm{CDCl}_{3}\right): \delta_{\mathrm{C}}=165.66,165.28,150.80,150.09,142.46,141.98,141.58,140.92,140.83$, $139.39,138.62,137.65,135.65,134.61,133.92$, 132.29, 131.15, 129.94, 128.82, 128.61, 127.35, 127.15, $126.83,126.69,122.55,118.32,115.55,115.28,77.36,77.10,76.85,59.89,51.22,39.19,24.65,14.65$ ppm; HRMS (FAB-MS): calcd for $\mathrm{C}_{47} \mathrm{H}_{41} \mathrm{NO}_{6}{ }^{+}[\mathrm{M}]^{+}$715.2934, found: 715.2963.

Compound 2e: The procedure used for the preparation of 2e was adopted here. The reaction of $1 \mathbf{e}$ (197 $\mathrm{mg}, 0.449 \mathrm{mmol})$ with benzoin $(280 \mathrm{mg}, 1.32 \mathrm{mmol})$ and ammonium acetate $(1.00 \mathrm{~g}, 13.0 \mathrm{mmol}) \mathrm{in}$ acetic acid $(3 \mathrm{~mL})$ at $100{ }^{\circ} \mathrm{C}$ for $15 \mathrm{~h}$ afforded $2 \mathrm{e}(187 \mathrm{mg}, 66 \%)$. Mp $287{ }^{\circ} \mathrm{C}$; IR (AT-IR): $v_{\max }=3255$ (w), 2956 (w), 1746 (s), 1655 (m), 1603 (m), 1544 (w), 1521 (m), 1509 (m), 1452 (m), 1436 (m), 1415 (m), $1391(\mathrm{w}), 1380$ (w), 1362 (w), 1326 (w), 1302 (w), 1272 (m), 1251 (w), 1222 (s), 1173 (w), 1121 (w), 1079 (w), 1067 (w), 1049 (w), 1008 (w), 967 (w), 939 (w), 903 (w), 893 (w), 874 (m), $840(w), 807$ (w), $778(\mathrm{~m}), 761(\mathrm{~m}), 734(\mathrm{w}), 701(\mathrm{~m}), 689(\mathrm{~m}), 668(\mathrm{w}) \mathrm{cm}^{-1}$; UV/Vis $\left(\mathrm{CH}_{2} \mathrm{Cl}_{2}\right): \lambda_{\max }(\log \varepsilon)=240$ (4.64), 280 (4.67), 320 sh (4.39), 387 (4.29), 402 sh (4.27), 592 sh (2.76) nm; ${ }^{1} \mathrm{H}$ NMR (500 MHz, DMSO- $\left.d_{6}\right): \delta_{\mathrm{H}}=11.81(\mathrm{~s}, 1 \mathrm{H}, \mathrm{NH}), 9.55(\mathrm{~s}, 1 \mathrm{H}, 4-\mathrm{H}), 8.27(\mathrm{~d}, 1 \mathrm{H}, J=10.0 \mathrm{~Hz}, 8-\mathrm{H}), 8.22(\mathrm{~s}, 1 \mathrm{H}, 2-\mathrm{H})$, 7.85 (d, 1H, $J=10.0 \mathrm{~Hz}, 6-\mathrm{H}), 7.35-7.31$ (m, 3H, 7-H and $\mathrm{Ph}-\mathrm{H}), 7.25$ (t, 2H, $J=7.7 \mathrm{~Hz}, \mathrm{Ph}-\mathrm{H})$, 7.10-7.19 (m, 6H, Ph-H), 6.79 (dd, 1H, $\left.J=11.7,9.2 \mathrm{~Hz}, 7^{\prime}-\mathrm{H}\right), 6.73$ (d, 1H, $J=9.2 \mathrm{~Hz}, 6$ '-H), 6.53 (d, $\left.1 \mathrm{H}, J=11.7 \mathrm{~Hz}, 8^{\prime}-\mathrm{H}\right), 6.50$ (s, 1H, 4'-H), 3.81 (s, 3H, $\mathrm{CO}_{2} \mathrm{Me}$ ), 3.14 (sept, 1H, $J=6.6 \mathrm{~Hz}, i-\mathrm{Pr}$ ), 2.29 (sept, $1 \mathrm{H}, J=6.6 \mathrm{~Hz}, i$-Pr), 1.29 (d, 6H, $J=6.6 \mathrm{~Hz}, i$-Pr), 0.76 (d, 3H, $J=6.6 \mathrm{H}, i$-Pr), 0.69 (d, 3H, $J=$ $6.6 \mathrm{~Hz}, i$-Pr); Low solubility of this compound hampered the measurement of ${ }^{13} \mathrm{C} \mathrm{NMR}$; HRMS (FAB-MS): calcd for $\mathrm{C}_{43} \mathrm{H}_{37} \mathrm{NO}_{4}{ }^{+}[\mathrm{M}]^{+}$631.2723, found: 631.2709 .

Compound 2f: The procedure used for the preparation of $\mathbf{2 f}$ was adopted here. The reaction of $\mathbf{1 f}(29 \mathrm{mg}$, $0.080 \mathrm{mmol})$ with benzoin $(53 \mathrm{mg}, 0.250 \mathrm{mmol})$ and ammonium acetate $(188 \mathrm{mg}, 2.43 \mathrm{mmol})$ in acetic 
acid $(0.6 \mathrm{~mL})$ at $100{ }^{\circ} \mathrm{C}$ for $15 \mathrm{~h}$ afforded $2 \mathrm{f}(12 \mathrm{mg}, 28 \%)$. Mp $116-117{ }^{\circ} \mathrm{C}$; IR (AT-IR): $v_{\max }=3431$ (w), 3055 (w), 2958 (w), 2925 (w), 1601 (s), 1571 (m), 1504 (s), 1486 (m), 1447 (m), 1428 (m), 1397 (m), 1353 (m), 1308 (w), 1251 (w), 1230 (w), 1179 (w), 1156 (w), 1102 (w), 1071 (m), 1031 (m), 1013 (w), 958 (w), 913 (m), 876 (m), 844 (s), 794 (s), 763 (s), 738 (m), 673 (s), 660 (w) cm ${ }^{-1}$; UV/Vis $\left(\mathrm{CH}_{2} \mathrm{Cl}_{2}\right)$ : $\lambda_{\max }(\log \varepsilon)=244$ (4.52), 300 (4.56), $325 \mathrm{sh}$ (4.41), 380 (4.05), 639 (2.68), $709 \mathrm{sh}$ (2.55) nm; ${ }^{1} \mathrm{H}$ NMR $\left(500 \mathrm{MHz}, \mathrm{CDCl}_{3}\right): \delta_{\mathrm{H}}=8.42(\mathrm{~m}, 2 \mathrm{H}, 4-\mathrm{H}$ and $\mathrm{NH}), 8.10(\mathrm{~s}, 1 \mathrm{H}, 8-\mathrm{H}), 7.99(\mathrm{~s}, 1 \mathrm{H}, 2-\mathrm{H}), 7.60(\mathrm{~d}, 2 \mathrm{H}, J=$ $7.7 \mathrm{~Hz}, \mathrm{Ph}-\mathrm{H}$ ), 7.48 (t, 2H, J=7.7 Hz, Ph-H), 7.42 (d, 1H, J=10.0 Hz, 6-H), 7.25 (br.s, 11H, Ph-H), 7.06 (t, 1H, $J=10.0 \mathrm{~Hz}, 5-\mathrm{H}$ ), 7.00 (br.s, 5H, Ph-H), 2.71 (sept, 1H, $J=6.9 \mathrm{~Hz}, i-\mathrm{Pr}$ ), 1.08 (d, 6H, $J=6.9 \mathrm{~Hz}$, $i$-Pr) ppm; ${ }^{13} \mathrm{C}$ NMR $\left(125 \mathrm{MHz}, \mathrm{CDCl}_{3}\right): \delta_{\mathrm{C}}=143.86,137.62,137.38,137.30,137.21,136.31,136.14$, $136.02,135.88,134.54,133.04,131.33,130.46,129.69,129.54,129.05,128.75,128.65,128.09,127.84$, $127.09,126.47,126.33,126.08,125.88,125.42,123.69,123.58,122.64,120.06,38.42,24.31$ ppm; HRMS (FAB-MS): calcd for $\mathrm{C}_{41} \mathrm{H}_{33} \mathrm{~N}^{+}[\mathrm{M}]^{+}$539.2613, found: 539.2632.

Compound 2g: The procedure used for the preparation of $\mathbf{2 g}$ was adopted here. The reaction of $\mathbf{1 g}$ (115 $\mathrm{mg}, 0.282 \mathrm{mmol})$ with benzoin $(183 \mathrm{mg}, 0.862 \mathrm{mmol})$ and ammonium acetate $(651 \mathrm{mg}, 8.45 \mathrm{mmol})$ in acetic acid $(2 \mathrm{~mL})$ at $100{ }^{\circ} \mathrm{C}$ for $15 \mathrm{~h}$ afforded $2 \mathrm{~g}(82 \mathrm{mg}, 50 \%)$. Mp 135-136 ${ }^{\circ} \mathrm{C}$; IR (AT-IR): $v_{\max }=$ 3434 (w), 3054 (w), 2959 (m), 1601 (m), 1572 (m), 1527 (m), 1511 (m), 1488 (m), 1444 (m), 1397 (m), 1352 (m), 1196 (m), 1133 (m), 1070 (m), 1025 (m), 947 (m), 903 (m), 877 (m), 820 (m), 796 (m), 782 (m), $762(\mathrm{~s}), 720(\mathrm{~m}), 699(\mathrm{~s}), 678(\mathrm{~m}), 664(\mathrm{~m}), 652(\mathrm{~m}) \mathrm{cm}^{-1}$; UV/Vis $\left(\mathrm{CH}_{2} \mathrm{Cl}_{2}\right): \lambda_{\max }(\log \varepsilon)=248$ (4.51), 292 (4.64), 299 sh (4.64), 326 sh (4.46), 402 sh (3.96), 652 (2.57) nm; ${ }^{1} \mathrm{H}$ NMR (500 MHz, $\mathrm{CDCl}_{3}$ ): $\delta_{\mathrm{H}}=8.39$ (br.s, 2H, 8-H, NH), 8.13 (br.s, 1H, 4-H), 8.00 (br.s, 1H, 2-H), 7.53-7.66 (m, 2H, Ph-H), 7.47-7.53 (m, 2H, Ph-H), 7.16-7.33 (m, 13H, 5,6-H, and Ph-H), 6.90 (br.s, 2H, o-H of $p$ - $\mathrm{Me}_{2} \mathrm{NPh}$ ), 6.51 (d, 2H, $J=8.0 \mathrm{~Hz}, m-\mathrm{H}$ of $\left.p-\mathrm{Me}_{2} \mathrm{NPh}\right), 2.82$ (s, 7H, $\left.\mathrm{NMe}_{2}, i-\mathrm{Pr}\right), 1.08$ (d, 6H, $J=6.9 \mathrm{~Hz}$, $i$-Pr) ppm; ${ }^{13} \mathrm{C}$ NMR (125 MHz, $\left.\mathrm{CDCl}_{3}\right): \delta_{\mathrm{C}}=147.42,143.80,137.91,137.33,136.28,135.97,134.42$, $133.18,131.39,131.18,129.71,129.59,128.73,128.09,127.07,126.31,125.98,123.63,123.28,122.59$, $120.48,113.46,77.37,77.11,76.85,41.35,38.42,24.36 \mathrm{ppm}$, some signals in the aromatic region were overlapped with the other signals; HRMS (FAB-MS): calcd for $\mathrm{C}_{43} \mathrm{H}_{38} \mathrm{~N}_{2}{ }^{+}[\mathrm{M}]^{+}$582.3035, found: 582.3018 .

Compound $\mathbf{2 h}$ : The procedure used for the preparation of $\mathbf{2 h}$ was adopted here. The reaction of $\mathbf{1 h}$ (31 $\mathrm{mg}, 0.076 \mathrm{mmol})$ with benzoin $(53 \mathrm{mg}, 0.25 \mathrm{mmol})$ and ammonium acetate $(175 \mathrm{mg}, 2.27 \mathrm{mmol})$ in acetic acid $(0.6 \mathrm{~mL})$ at $100{ }^{\circ} \mathrm{C}$ for $15 \mathrm{~h}$ afforded $\mathbf{2 h}(5 \mathrm{mg}, 11 \%)$. Mp $260{ }^{\circ} \mathrm{C}$; IR (AT-IR): $v_{\max }=3362$ (w), 3056 (w), 2964 (w), 2927 (w), 1596 (m), 1505 (s), 1487 (w), 1461 (w), 1447 (w), 1430 (w), 1397 (w), 1334 (s), 1260 (w), 1177 (w), $1111(\mathrm{w}), 1071$ (w), 1031 (w), 946 (w), $911(\mathrm{w}), 856(\mathrm{~m}), 789(\mathrm{w}), 765$ (m), 
$727(\mathrm{w}), 700(\mathrm{~s}), 676(\mathrm{w}) \mathrm{cm}^{-1}$; UV/Vis $\left(\mathrm{CH}_{2} \mathrm{Cl}_{2}\right): \lambda_{\max }(\log \varepsilon)=244$ (4.58), $287 \mathrm{sh}$ (4.62), 301 (4.69), $325 \mathrm{sh}$ (4.55), 366 (4.22), $468 \mathrm{sh}$ (3.55), 629 (2.63), $695 \mathrm{sh}(2.51) \mathrm{nm} ;{ }^{1} \mathrm{H}$ NMR (500 MHz, $\left.\mathrm{CDCl}_{3}\right): \delta_{\mathrm{H}}=$ $8.53(\mathrm{~s}, 1 \mathrm{H}, \mathrm{NH}), 8.46(\mathrm{~d}, 1 \mathrm{H}, J=9.7 \mathrm{~Hz}, 8-\mathrm{H}), 7.99(\mathrm{~m}, 2 \mathrm{H}, 2,4-\mathrm{H}), 7.82$ (d, 2H, $J=8.5 \mathrm{~Hz}, m-\mathrm{H}$ of $\left.p-\mathrm{NO}_{2} \mathrm{Ph}\right), 7.60(\mathrm{~d}, 2 \mathrm{H}, J=7.7 \mathrm{~Hz}, \mathrm{Ph}-\mathrm{H}), 7.45-7.51(\mathrm{~m}, 3 \mathrm{H}, 6-\mathrm{H}$ and $\mathrm{Ph}-\mathrm{H}), 7.36(\mathrm{t}, 1 \mathrm{H}, J=7.3 \mathrm{~Hz}$, Ph-H), 7.25-7.30 (m, 8H, Ph-H), 7.20-7.23 (m, 2H, Ph-H), 7.12 (t, 1H, J=10.0 Hz, 5-H), 7.07 (d, 2H, $J$ $=8.5 \mathrm{~Hz}, o-\mathrm{H}$ of $\left.p-\mathrm{NO}_{2} \mathrm{Ph}\right), 2.69(\mathrm{t}, 1 \mathrm{H}, J=6.9 \mathrm{~Hz}, i-\mathrm{Pr}), 1.03(\mathrm{~d}, 6 \mathrm{H}, J=6.9 \mathrm{~Hz}, i-\mathrm{Pr}) \mathrm{ppm} ;{ }^{13} \mathrm{C} \mathrm{NMR}$ $\left(125 \mathrm{MHz}, \mathrm{CDCl}_{3}\right): \delta_{\mathrm{C}}=145.23,144.29,143.73,138.01,137.13,136.99,136.88,136.66,136.24,135.30$, $135.07,132.40,131.20,130.50,129.97,129.85,129.68,128.85,128.78,128.53,127.11,126.93,126.74$, $126.60,124.30,123.21,122.43,121.43,118.75,38.54,24.31 \mathrm{ppm}$, two signals in the aromatic region are overlapped with the other signals; HRMS (FAB-MS): calcd for $\mathrm{C}_{41} \mathrm{H}_{32} \mathrm{~N}_{2} \mathrm{O}_{2}{ }^{+}[\mathrm{M}]^{+}$584.2464, found: 584.2478 .

\section{ACKNOWLEDGEMENTS}

This work was supported by JSPS KAKENHI Grant Number JP25810019 and 17K05780, and also by a research grant from the Faculty of Science, Shinshu University.

\section{REFERENCES AND NOTES}

1. a) E. Baltazzi and L. I. Krimen, Chem. Rev., 1963, 63, 511; b) B. A. Trofimov, L. N. Sobenina, A. P. Demenev, and A. I. Mikhaleva, Chem. Rev., 2004, 104, 2481; c) V. Estévez, M. Villacampa, and J. C. Menéndez, Chem. Soc. Rev., 2014, 43, 4633.

2. a) T. Bando and H. Sugiyama, Acc. Chem. Res., 2006, 39, 935; b) H. Fan, J. Peng, M. T. Hamann, and J.-F. Hu, Chem. Rev., 2008, 108, 264; c) V. Bhardwaj, D. Gumber, V. Abbot, S. Dhimana, and P. Sharma, $R S C A d v ., 2015,5,15233$; d) L. M. D. Coen, T. S. A. Heugebaert, D. García, and C. V. Stevens, Chem. Rev., 2016, 116, 80.

3. a) X. Feng, B. Tong, J. Shen, J. Shi, T. Han, L. Chen, J. Zhi, P. Lu, Y. Ma, and Y. Dong, J. Phys. Chem. B, 2010, 114, 16731; b) C.-S. Li, Y.-H. Tsai, W.-C. Lee, and W.-J. Kuo, J. Org. Chem., 2010, 75, 4004; c) T. Taniguchi, J. Wang, S. Irle, and S. Yamaguchi, Dalton Trans., 2013, 42, 620; d) S. Suzuki and J. Yamaguchi, Chem. Commun., 2017, 53, 1568.

4. a) L. Knorr, Ber. Dtsch. Chem. Ges., 1884, 17, 1635; b) C. Paal, Ber. Dtsch. Chem. Ges., 1885, 18, 367.

5. O. Piloty, Chem. Ber., 1910, 43, 489.

6. T. T. Dang, R. Ahmad, T. T. Dang, H. Reinke, and P. Langer, Tetrahedron Lett., 2008, 49, 1698.

7. a) V. V. Diev, O. N. Stetsenko, T. Q. Tung, J. Kopf, R. R. Kostikov, and A. P. Molchanov, J. Org. Chem., 2008, 73, 2396; b) L. D. Funt, O. A. Tomashenko, A. F. Khlebnikov, M. S. Novikov, and A. 
Y. Ivanov, J. Org. Chem., 2016, 81, 11210.

8. a) K.-P. Zeller, Azulene in Methoden der Organischen Chemie (Houben-Weyl), 4th edn., ed. by H. Kropf, Thieme, Stuttgart, 1985, Vol. V, Part 2c, p 127; b) G. Fischer, Adv. Heterocycl. Chem., 2009, 97, 131; c) S. Ito and N. Morita, Eur. J. Org. Chem., 2009, 4567; d) S. Ito, T. Shoji, and N. Morita, Synlett, 2011, 2279; e) T. Shoji and S. Ito, Chem. Eur. J., 2017, in press (DOI: 10.1002/chem.201702806).

9. a) P. Cowper, Y. Jin, M. D. Turton, G. Kociok-Köhn, and S. E. Lewis, Angew. Chem. Int. Ed., 2016, 55, 2564; b) F. Schwarz, M. Koch, G. Kastlunger, H. Berke, R. Stadler, K. Venkatesan, and E. Lçrtscher, Angew. Chem. Int. Ed., 2016, 55, 6103; c) H. Xin, C. Ge, X. Yang, H. Gao, X. Yanga, and X. Gao, Chem. Sci., 2016, 7, 6701; d) M. Murai, M. Yanagawa, M. Nakamura, and K. Takai, Asian J. Org. Chem., 2016, 5, 629; e) D. Lichosyt, P. Dydio, and J. Jurczak, Chem. Eur. J., 2016, 22, 17673; f) A. E. Ion, L. Cristian, M. Voicescu, M. Bangesh, A. M. Madalan, D. Bala, C. Mihailciuc, and S. Nica, Beilstein J. Org. Chem., 2016, 12, 1812; g) T. O. Leino, N. G. Johansson, L. Devisscher, N. Sipari, J. Yli-Kauhaluoma, and E. A. A. Wallén, Eur. J. Org. Chem., 2016, 5539; h) Y. Yamaguchi, M. Takubo, K. Ogawa, K.-i. Nakayama, T. Koganezawa, and H. Katagiri, J. Am. Chem. Soc., 2016, 138, 11335; i) Y. Chen, Y. Zhu, D. Yang, S. Zhao, L. Zhang, L. Yang, J. Wu, Y. Huang, Z. Xu, and Z. Lu, Chem. Eur. J., 2016, 22, 14527; j) T. Koide, M. Takesue, T. Murafuji, K. Satomi, Y. Suzuki, J. Kawamata, K. Terai, M. Suzuki, H. Yamada, Y. Shiota, K. Yoshizawa, and F. Tani, ChemPlusChem, 2016, in press (DOI:10.1002/cplu.201600356); k) T. Shoji, S. Sugiyama, T. Araki, A. Ohta, R. Sekiguchi, S. Ito, S. Mori, T. Okujima, and M. Yasunami, Org. Biomol. Chem., 2017, 15, 3917.

10. K. Kurotobi, H. Tabata, M. Miyauchi, T. Murafuji, and Y. Sugihara, Synthesis, 2002, 1013.

11. H. Salman, Y. Abraham, S. Tal, S. Meltzman, M. Kapon, N. Tessler, S. Speiser, and Y. Eichen, Eur. J. Org. Chem., 2005, 2207.

12. Y. M. Poronik, L. M. Mazur, M. Samoć, D. Jacquemin, and D. T. Gryko, J. Mater. Chem. C, 2017, 5, 2620.

13. a) T. Shoji, R. Yokoyama, S. Ito, M. Watanabe, K. Toyota, M. Yasunami, and N. Morita, Tetrahedron Lett., 2007, 48, 1099; b) T. Shoji, S. Ito, M. Watanabe, K. Toyota, M. Yasunami, and N. Morita, Tetrahedron Lett., 2007, 48, 3009; c) T. Shoji, S. Ito, T. Okujima, J. Higashi, R. Yokoyama, K. Toyota, M. Yasunami, and N. Morita, Eur. J. Org. Chem., 2009, 1554; d) T. Shoji, S. Ito, K. Toyota, and N. Morita, Eur. J. Org. Chem., 2010, 1059; e) T. Shoji, K. Okada, S. Ito, K. Toyota, and N. Morita, Tetrahedron Lett., 2010, 51, 5127; f) T. Shoji, S. Ito, J. Higashi, and N. Morita, Eur. J. Org. Chem., 2011, 5311; g) T. Shoji, Y. Inoue, S. Ito, T. Okujima, and N. Morita, Heterocycles, 2012, 85, 35; h) T. Shoji, A. Maruyama, M. Maruyama, S. Ito, T. Okujima, J. Higashi, K. Toyota, 
and N. Morita, Bull. Chem. Soc. Jpn., 2014, 87, 141; i) T. Shoji, A. Maruyama, T. Araki, S. Ito, and T. Okujima, Org. Biomol. Chem., 2015, 13, 10191; j) T. Shoji, A. Maruyama, S. Ito, T. Okujima, M. Yasunami, J. Higashi, and N. Morita, Heterocycles, 2014, 89, 2588; k) T. Shoji, T. Araki, S. Sugiyama, A. Ohta, R. Sekiguchi, S. Ito, T. Okujima, and K. Toyota, J. Org. Chem., 2017, 82, 1657; 1) T. Shoji, D. Nagai, M. Tanaka, T. Araki, A. Ohta, R. Sekiguchi, S. Ito, S. Mori, and T. Okujima, Chem. Eur. J., 2017, 23, 5126.

14. T. Shoji, Y. Inoue, and S. Ito, Tetrahedron Lett., 2012, 53, 1493.

15. X. Wu, K. Li, S. Wang, C. Liu, and A. Lei, Org. Lett., 2016, 18, 56.

16. F. Tamaddon, A. D. Tafti, and F. Pooramini, Synthesis, 2016, 48, 4295.

17. T. Shoji, M. Tanaka, T. Araki, S. Takagaki, R. Sekiguchi, and S. Ito, RSC Adv., 2016, 6, 78303.

18. T. Shoji, A. Maruyama, M. Tanaka, D. Nagai, E. Shimomura, K. Fujimori, S. Ito, T. Okujima, K. Toyota, and M. Yasunami, ChemistrySelect, 2016, 1, 49.

19. The B3LYP/6-31G** time-dependence density functional calculations were performed with Spartan'10, Wavefunction, Irvine, CA. 